\title{
ブレーキの摩擦カが変化する要因に関する研究* (摩擦面温度の数值計算と計測)
}

\section{Study for the Factors of Fluctuating Brake Friction Force (Numerical Calculation and Measurement of Friction Surface Temperature)}

\author{
Ryoichi KURASAKO *1 \\ ${ }^{* 1}$ TOYOTA MOTOR CORPORATION, \\ Mishuku 1200, Susono, Shizuoka, 410-1193, Japan
}

\begin{abstract}
Demands to vehicles performance from environmental view points are growing these days. Lightening each part is needed as one method to improve the Fuel Economy of the car. The main role of brakes is to transfer the kinematic energy of the vehicle to the dissipative thermal energy, and accordingly to lead the deceleration of the vehicle. On the other hand, a steady braking performance is important because it drives comfortably. The appropriate design of brakes for the stable performance requires the understanding of the temperature distribution based on the analysis of heat transfer. The friction force in a brake system is generated by making contact of the pad with the rotor. This study presumed that the friction force is depending upon the temperature of the surface where the pad and rotor come in contact. This study proposed a calculation method for estimating the temperature of the friction surface. Moreover, this study conducted the experiments to compare with the estimates from the proposed method. The experimental results agree with the estimations calculated from the proposed method. Based on the temperature distribution calculated by this method, considering how the shapes of the pad have an influence on the generated brake force.
\end{abstract}

Key Words : Heat Transfer Design, Transient Heat Transfer, Tribology, Disc Brake, Friction Surface

\section{1. 緒言}

自動車の環境性能に対する要求が高くなっており, 燃費を向上するひとつの方法として, 各部品質量の軽量化 が必要になっている.ブレーキの主な役割は, 運動エネルギーを摩擦により熱エネルギーに変換し, 車両を減速 させることであり，熱容量の観点からブレーキロータ摺動部質量が設計諸元のひとつとなっている，一方で，快 適にドライブするために，安定した制動性能は重要である．そこで，効率的なブレーキ設計のために，熱解析が 必要になる. ブレーキの熱解析に関して, 戎ら ${ }^{(5)}$ は粒子法を用いたディスクブレーキの非定常熱応力問題の解析 を行いフィンの効果を確認している. また, C.H.Gao ら ${ }^{(3)}$ は, ディスクブレーキの 3 次元熱応力解析を行ってお り, Talati ら (4) は, パッドとロータの熱浸透率を考慮した熱伝導解析を行っている. 本研究では, ブレーキのパ ッドとロータ間の摩擦面温度がドライバーの操作力と摩擦力の関係に影響すると考えた，そこで，主に企画段階 での活用を考慮した摩擦面温度を推定する計算手法を提案する. それは、摩擦面形状が摩擦面温度と制動性能に 及ぼす影響を確認することを目的としている．乗用車ではフロントブレーキの熱負荷が高く，ディスクブレーキ がほぼ全車に採用されていることから，ディスクブレーキについて解析を行うこととした。

\section{2. 摩擦面温度解析の意義}

\footnotetext{
* 原稿受付 2011 年 10 月 30 日

*1 正員, トヨタ自動車（株）（广410-1193 静岡県裾野市御宿 1200）

E-mail: ryou-k@kurasako.tec.toyota.co.jp
} 
ディスクブレーキは, 図 1 に示すように回転するロータにパッドを押付ける構造である. パッドをローターに 押付ける部品をキャリパと呼ぶ. 油圧によってキャリパのシリンダ内にあるピストンを作動し, キャリパのシリ ンダからピストンと反対側のパッドまで伸びた部材との間でパッドを挟む構造である.

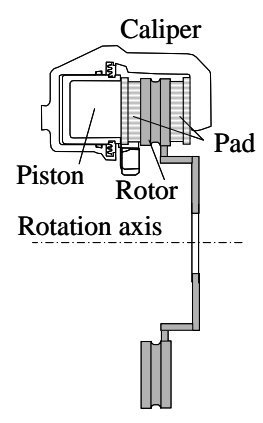

Fig.1 Cross section of disc brake

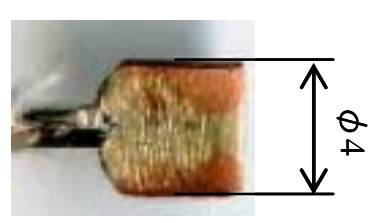

Fig.2 Cross section of thermocouple

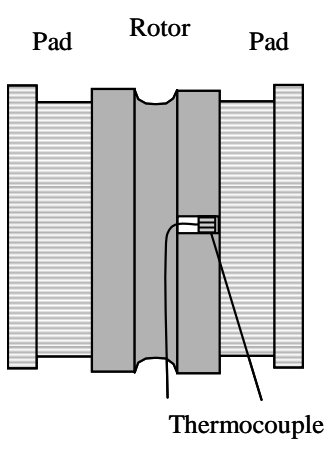

Fig.3 Thermocouple in the rotor

試験設備にブレーキ部品を取付けて行う試験（以後, 台上試験という）でのブレーキロータの温度計測は, 図 2 に断面を示寸直径 $4 \mathrm{~mm}$, 長さ $4 \mathrm{~mm}$ の $\mathrm{K}$ 型熱電対を図 3 に示すようにロータに穴を開けて圧入して行った. 熱 電対の温度計測位置は，2 本の導線の接触部分である. 毎回切断して確認することは困難であるため, 図 2 の形 状範囲内であることから摩擦面より数 $\mathrm{mm}$ 深い位置でと推定される. また, 熱電対はパッドと直接接触して摩擦 を行わないように設置するため, 平均的な温度変化を計測するには適している. しかし, 通常の熱電対は, ブレ 一キロータがパッドを通過する前後の $5 \mathrm{~ms}$ 程度の短時間かつブレーキロータ表面近傍の非定常な温度変化に対応 した時間応答性がない.

過去の台上試験において図 4 に示すようにして，赤外線カメラ（Radians HS_140frame/s）で計測した温度イメ 一ジ画像の結果を図 5 に示寸. 制動条件は車速 $64 \mathrm{~km} / \mathrm{h}$ から減速度 $3.5 \mathrm{~m} / \mathrm{s}^{2}$ である. ロー夕のある位置が時計回り に一回転する間のパッド入口, 出口, 次のパッド入口に着目して温度イメージを表示している. 赤外線カメラは, 表面温度とその表面の赤外線放射率に比例した赤外線放射量分布を計測する装置である．ブレーキロータの表面 は，摩擦することで移着膜の形成や剥離，研削などの影響により放射率が変化するため，赤外線カメラでは温度

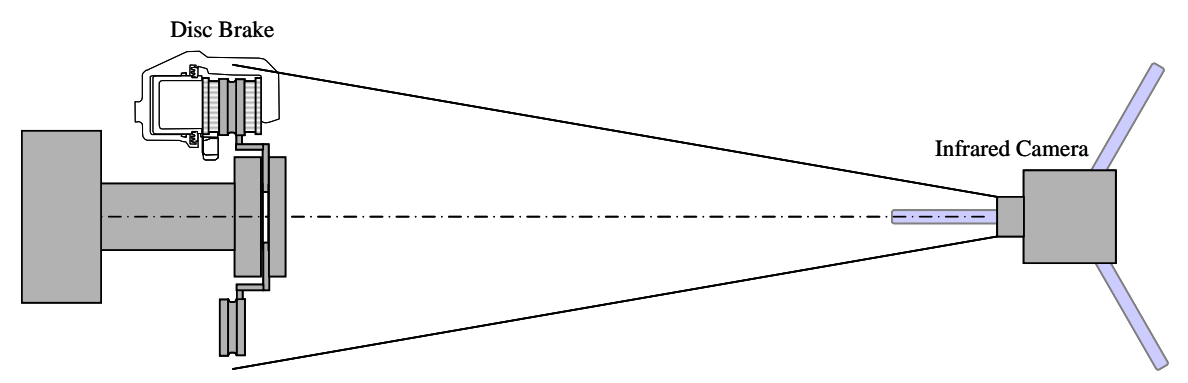

Fig.4 Measurement outline chart in infrared camera in plane view

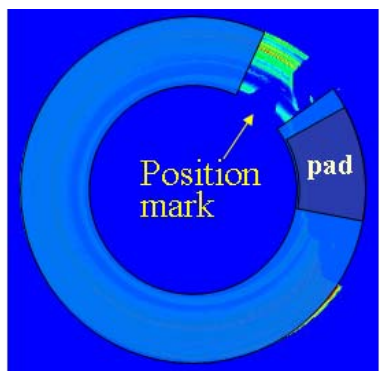

(a) Before pad entrance

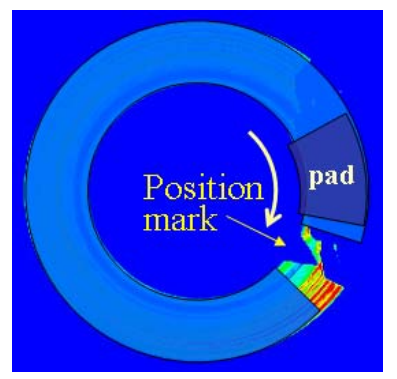

(b) After pad exit

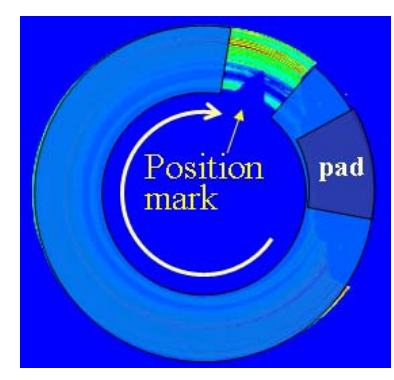

(c) Before next pad entrance

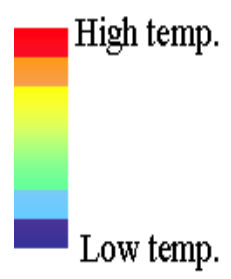

(d) color map of temperature

Fig.5 Friction surface temperature image of brake rotor one revolution with infra red camera. 
変化のイメージは把握できるが，実際の温度の值を計測することは困難である. しかし，図 5 の(d)カラーマップ に示すように赤色側は赤外線放射量が多く高温で，青色側は赤外線放射量が少なく低温であることをイメージ画 像として捕らえることは出来る. 図 5 の(a)パッド入口から(b)パッド出口で赤色が増加し， (c)次のパッド入口ま でに赤色が減少する様子から，実際には摩擦面での温度変化は非常に大きいことが推測される.

次に摩擦面形状が摩擦面温度およびブレーキの効きに影響すると考え, 台上試験を行った. 図 1 に示寸ロータ, キャリパは同一品を用いることとして，パッド摩擦面形状のみを変更することで対応した．計算を行うことを前 提にして, 実験に用いるパッド形状は図 6 に示寸扇型（a）Base と呼ぶ形状を基準にした. 図心位置の変化が少 ないように円周方向の巾を Base 形状に対して 35\%小さくした（b）R/C と呼ぶ形状，半径方向巾を $17 \%$ 小さくし た（c） R/R と呼ぶ形状を供試品とした. 出力であるブレーキトルクと入力である油圧の関係（ブレーキの効きと いう）の違いを確認することとした．台上試験の条件は，JASO（Japanese Automotive Standards Organization，日本 自動車技術会規格）C402の乗用車常用ブレーキ実車試験方法にほぼ準じて行った。

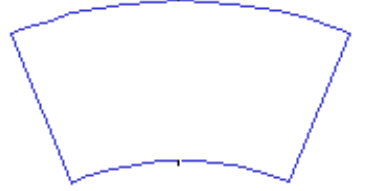

(a) Base. Internal and external radius is same as brake rotor.

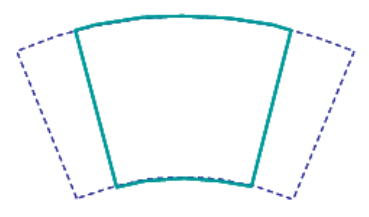

(b) Reduce/Circumferential width, $65 \%$ as Base. Call R/C.

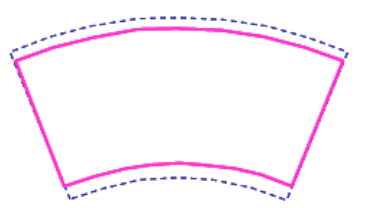

(c) Reduce/ Radial width, $83 \%$ as Base. Call R/R.

Fig.6 Three kind of Pad shapes.

パッド形状違いによるブレーキの効きに変化があった制動条件は, 制動初速 $130 \mathrm{~km} / \mathrm{h}$ から減速度 $7 \mathrm{~m} / \mathrm{s}^{2}$ で制動 を行うように制御したときである。その試験結果を時間軸波形としてパッド形状ごとに図 7 に示す．図７（a）に 示す形状 Base の結果を見ると，ほぼ一定のトルクを維持するための油圧は，初期 $5 \mathrm{MPa}$ 程度に上昇後，すぐに減 少し始めそのまま徐々に減少させながら制御されている，これは，ブレーキの効きが 1 制動中に高くなっている ことを意味している，一般に制動を行うとブレーキロータ，パッドの温度が上昇して熱膨張によってパッド，口 一タの厚さが増加する.ペダルからディスクブレーキまでの抵抗を考慮すると熱膨張によりパッド押付け方向の 力が増加する. したがって, 摩擦係数が一定であれば効きは高くなる. 図 7 (b) に示寸形状 R/C の結果を見ると, ほぼ一定のトルクを維持するための油圧は，初期に Base,およびR/R 形状より高いが，すぐに減少を始めた後，

Base 形状と同様に徐々に減少させながら制御されている. これに対して, 図 7 (c) に示寸形状 R/R の結果を見る と, ほぼ一定のトルクを維持するための油圧は, 初期に Base と同等で, 寸ぐに減少し始めた後, およそ $1.5 \mathrm{~s} \sim 3.5 \mathrm{~s}$ の間から徐々に増加させながら制御されている。この結果から，BaseおよびR/C 形状に対して，R/R 形状は 1 制 動中に同じ出力を得るための入力方法が異なることがわかる.

この実験でのロータ温度は, 図 2 に示寸熱電対で計測している. 図 7 の(a)(b)(c)各グラフに示すロータ温度は, パッド通過時の変化は見られず，連続的に上昇している様子が計測されている.

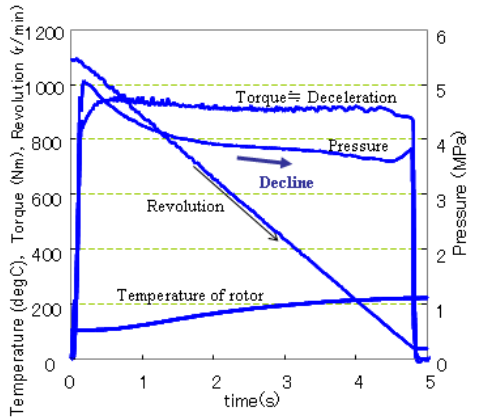

(a) Pad shape is Base

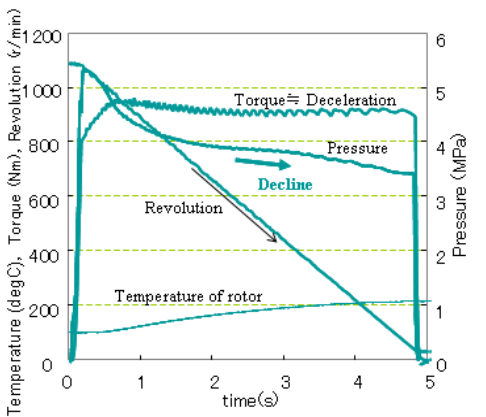

(b) Pad shape is R/ C

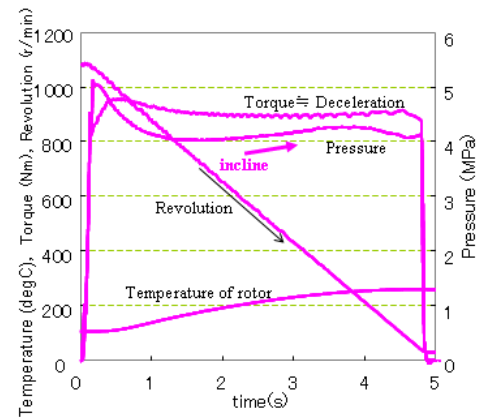

(c) Pad shape is $\mathrm{R} / \mathrm{R}$

Fig.7 Experimental result, brake effectiveness test. 
赤外線カメラの計測結果も合わせて考えると，ブレーキの効きにパッドとロータの接触する摩擦面形状の影響 が大きいと推測される. 本研究では, 設計的にブレーキの効きを安定させるため, 企画段階で摩擦面形状を決め るのに摩擦面温度を把握することが有効と考え, 摩擦面温度を計算で求める方法検討する.

\section{3. 摩擦面温度計算手法}

\section{$3 \cdot 1$ 熱伝導モデル}

出来るだけ，簡単なモデルとするための仮定 4 つを示す.

最初に, 円周方向へのエネルギー移動はないと考える. 理由は, ロータ円周方向の温度差は, 表面温度と熱電 対温度の関係から厚さ方向の温度差に比べ，隣り合った同じ距離の点間では小さいと推定される. また，円周方 向の隣り合った点は時間経過とともにエネルギーの入出力の関係が順次入れ替わることになるためである.

次に半径方向へのエネルギー移動はないと考える. 外周円筒面での冷却, 内周側のハット部分への熱伝導があ ることから制動有効半径位置と両端部で温度差が発生すると考えられる。しかし，一制動中の制動有効半径位置 近傍では円周方向と同様に，半径方向の温度差は厚さ方向の温度差に比べて小さいと推定される.

3 番目にパッドとロータの接触面圧は均一とする. 企画段階で摩擦面形状設計を行う際には, 製造公差や偏摩 耗，変形，荷重などの要因で不均一な面圧になることを理解した上で，理想状態の性能を確保する.

4 番目にロータへのエネルギー流入率を設定することでパッドへの伝導を省略する. パッドの熱特性が解って いる場合は，熱浸透率と面積からエネルギー流入率を求める.

以上の仮定を考慮した摩擦面温度計算のモデル概念図を図 8 に示す，パッド形状は扇型とし， ロータ有効半径 上の 1 点がパッドを通過し，パッド入り口の直前まで戻ってくる 1 回転中の厚さ方向温度変化を時刻歴で表した 時間空間モデルである.このモデルを用いて計算を行う際のエネルギー収支について，エネルギー入力はロータ 制動有効半径上の 1 点がパッドを通過する時入口から出口まで，エネルギー放出についてパッド通過中は厚さ方 向への伝導のみ, パッド通過後次のパッド入り口までは厚さ方向伝導と空気へ伝達とする.

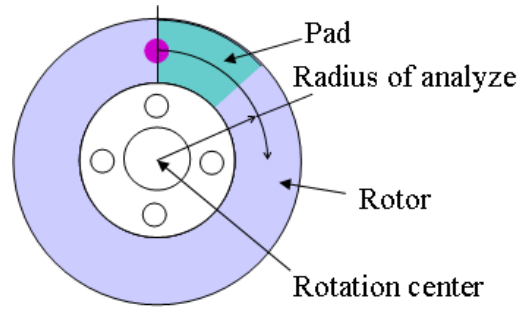

(a) outline drawing

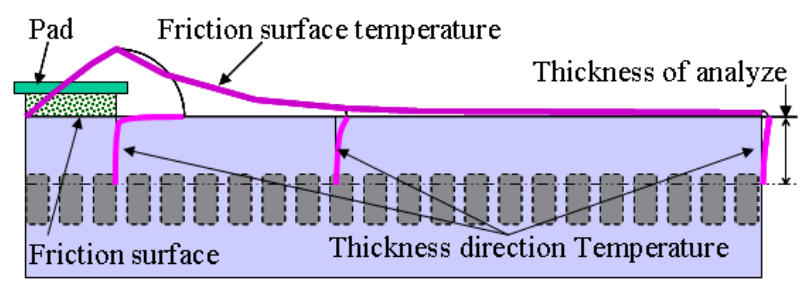

(b)Section of analyze

Fig.8 One revolution of brake rotor, model image of friction surface temperature and thickness direction temperature.

\section{$3 \cdot 2$ 熱伝導の数式化}

時間と厚さ方向 1 次元を扱う熱伝導方程式は一般に次式のように導かれる ${ }^{(1)}$ (2).$a$ は熱拡散率であり, 熱伝導 率 $\lambda$, 比熱 $c$, 密度 $\rho$ を用いて式 (2) のように表される.

$$
\begin{aligned}
& \frac{\partial T}{\partial t}=a \frac{\partial^{2} T}{\partial x^{2}} \\
& a=\frac{\lambda}{c \rho}
\end{aligned}
$$


しかし，ブレーキに適用する場合，境界条件が変化し続けるため，解析解を得ることは非常に困難である．この

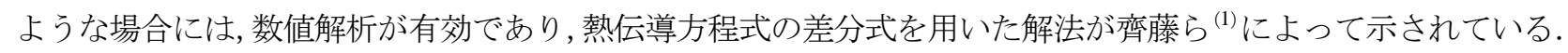

図 9 に示寸厚さ方向を $n$ 分割した位置に○印で示寸温度を代表する点 $j=0 \sim n$ を置いた齊藤ら ${ }^{(1)}$ のモデルを用い ることにした. このモデルの厚さ方向任意の点 $j$ の時間 $t_{k}$ での温度は, 式 (3) のように求められている ${ }^{(1)}$. 本 研究では, 摩擦面温度を車両諸元, ブレーキ諸元を直接的に扱い計算可能と寸るため, 式 (3) の刻み時間を一定 でなく $\Delta t_{k}$ と置いて時間の関数としている. なぜなら, 速度は減速し変化する. 一方でエネルギー入力を考慮し て，ロータの一点がパッドと摺動する巾を一定にするため，回転方向の刻み角度を一定にする必要がある．した がって, 刻み時間は時間 $t_{k}$ と時間 $t_{k-1}$ の差として求める. 時間と回転角度の関係は次項で求める. 解析厚さ $l$ は, 分割厚さ $\Delta x$ の $n$ 倍とする.

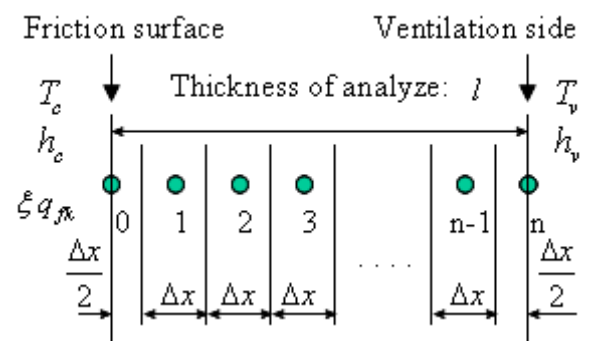

Fig.9 Rotor model for thickness direction

$$
\begin{aligned}
& T_{j}^{k}=T_{j}^{k-1}+\frac{a \Delta t_{k}}{(\Delta x)^{2}}\left(T_{j-1}^{k-1}-2 T_{j}^{k-1}+T_{j+1}^{k-1}\right) \quad \text { 但し, } 0<k, 1 \leq j \leq \mathrm{n}-1 \\
& \Delta t_{k}=t_{k}-t_{k-1} \\
& l=n \Delta x
\end{aligned}
$$

\section{$3 \cdot 3$ 初期条件と境界条件}

計算は，パッド入口から出口，次の入口までの 1 回転を基本として，ブレーキ終了まで行う。初期条件は計算 開始時間 $t_{0}$ での各点 $j=0 \sim n$ 温度を制動開始時のロータ温度 $T_{i}$ とする.

$$
T_{j}^{0}=T_{i} \quad(j=0 \sim n)
$$

次に摩擦面側パッド通過中の境界条件を設定する. 時間 $t_{k}$ での境界条件は, 時間 $t_{k-1}$ での摩擦面温度に時間 $t_{k-1}$ か ら時間 $t_{k}$ での単位時間あたりの摩擦面温度変化と刻多時間の積を加えて求める.

$$
T_{0}^{k}=T_{0}^{k-1}+\frac{d T_{0}^{k}}{d t} \Delta t_{k}
$$

時間 $t_{k-1}$ から時間 $t_{k}$ での単位時間あたりの摩擦面温度の変化は, パッド通過中と通過後で異なる. パッド通過中は, $3 \cdot 4$ 項で求める摩擦による単位面積当たり入力エネルギー率 $q_{f k}$ とロータへのエネルギー流入割合 $\xi$ を用いて下式 のように求める. 


$$
\frac{d T_{0}^{k}}{d t}=\frac{2 a}{\Delta x^{2}}\left(\frac{\xi q_{f k}}{\lambda} \Delta x+T_{1}^{k-1}-T_{0}^{k-1}\right) \quad\left(0<k \leq k_{p}\right) \quad k_{p} \text { パッド出口位置 }
$$

パッド通過後は，大気への熱伝達率 $h c$ と大気温度 $T c$ を用いて下式のように求める.

$$
\frac{d T_{0}^{k}}{d t}=\frac{2 a}{\Delta x^{2}}\left(\frac{h_{c}}{\lambda}\left(T_{c}-T_{0}^{k-1}\right) \Delta x+T_{1}^{k-1}-T_{0}^{k-1}\right) \quad\left(k_{p}<k \leq k_{2 \pi}\right) k_{2 \pi}: 1 \text { 回転終了位置 }
$$

続いてベンチレーション側の境界条件を設定する，時間 $t_{k}$ での境界条件は，時間 $t_{k-1}$ でのベンチレーション側 温度に時間 $t_{k-1}$ から時間 $t_{k}$ での単位時間あたりのベンチレーション側温度変化と刻み時間の積を加えて求める.

$$
T_{n}^{k}=T_{n}^{k-1}+\frac{d T_{n}^{k}}{d t} \Delta t_{k}
$$

時間 $t_{k-1}$ から時間 $t_{k}$ での単位時間あたりのベンチレーション側温度の変化は, 熱伝達率 $h v$ と通風温度 $T v$ を用いて 下式のように求める.

$$
\frac{d T_{n}^{k}}{d t}=\frac{2 a}{\Delta x^{2}}\left(\frac{h_{V}}{\lambda}\left(T_{v}-T_{n}^{k-1}\right) \Delta x+T_{n-1}^{k-1}-T_{n}^{k-1}\right) \quad\left(0<k \leq k_{2 \pi}\right) k_{2 \pi}: 1 \text { 回転終了位置 }
$$

式（6）から（11）が，制動開始時にパッド入口にあるロータ上の点がパッドを通過し，1回転する間の初期条 件および境界条件である. 2 回転目は 1 回転目終了時点の温度分布を初期条件とする. 3 回転目以降も同様に指定 条件になるまで繰り返すことで 1 制動中の温度変化が計算可能となる.

但し, 速度が低くなると時間 $\Delta t$ が長くなり, 分割厚さ $\Delta x$ との関係から計算できなくなる下限速度が存在する. 計算可能な条件は, 時間 $t_{k-1}$ の温度の係数が 0 以上である. 必要な速度まで計算可能なように, 厚さ方向の分割数 を減少することや円周方向の分割数を増加する対応が必要となる.

\section{$3 \cdot 4$ エネルギー入カと計算諸元}

摩擦面温度を計算するために図 9 に示し, 式 (8) で用いた摩擦による単位面積当たり入力エネルギー率を求め る. ブレーキロータ上の 1 点について解析を行うため, 車両諸元と制動減速度, ブレーキ諸元から決まる単位面 積当りの摩擦力に速度を掛けて求められる. 計算に必要な車両諸元とブレーキ諸元を図 10 に示す.

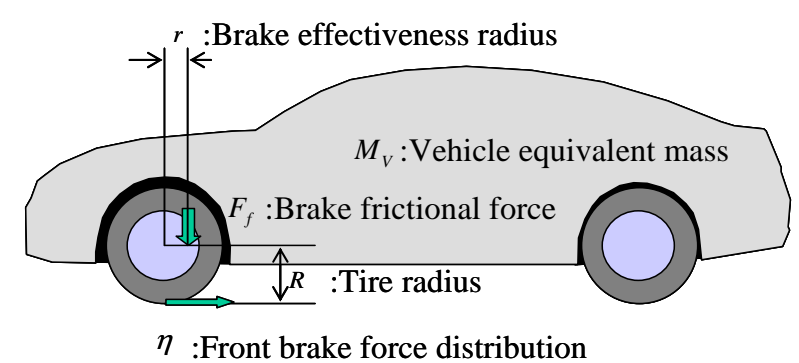

Fig.10 Vehicle specification, brake force distribution and frictional force. 
フロント制動力配分を $\eta$ としてフロント 1 輪が分担する質量 $M_{1}$ を式 (12) で求める. 制動減速度を $\alpha_{D}$ として, ブレーキ摩擦力 $F_{f}$ を式 (13) で求め, パッド 1 枚の面積を $A_{P}$ とし, パッド面圧 $P_{f}$, 摩擦係数 $\mu$ の積である単位 面積摩擦力を式（14）で求める.

$$
\begin{aligned}
& M_{1}=\frac{1}{2} M_{V} \cdot \eta \\
& F_{f}=M_{1} \alpha_{D} \frac{R}{r} \\
& \mu P_{f}=\frac{F_{f}}{2 A_{P}}
\end{aligned}
$$

時間 $t_{k}$ での車速 $V_{T k}$ を制動開始速度 $V_{T 0}$ と減速度から求める. 摩擦速度 $V_{f k}$ をタイヤ半径 $\mathrm{R}$, 制動有効半径 $\mathrm{r}$ から 求め, 式（14）と式（16）から求まる平均車速との積で単位面積当たりエネルギー率 $q_{k k}$ を求める.

$$
\begin{aligned}
& V_{T k}=\left(V_{T 0}-\alpha_{D} t_{k}\right) \\
& V_{f k}=V_{T k} \frac{r}{R} \\
& q_{f k}=\mu P_{f} \cdot \frac{V_{f k-1}+V_{f k}}{2}
\end{aligned}
$$

パッド円周方向すなわちロータ回転方向の刻み角度を一定にする．刻み角度の設定によるパッドの実巾とモデル 巾の差は, 入力エネルギー量を合わせるように面圧で補正する. 車速変化に対応して刻み時間が変化するため, 時間とロータ位置の関係付けが必要になる. ディスクロータの刻み角度を $\Delta \phi$ と置いた時, 時間 $t_{k}$ とロータ位置 $k \Delta \phi$ との関係は以下のように求められる.

$$
t_{k}=\frac{V_{T 0}-\sqrt{V_{T 0}{ }^{2}-\alpha_{D} 2 R k \Delta \phi}}{\alpha_{D}}
$$

以上が減速中の単位面積当たり入力エネルギー率，ならびにロータ位置に対する時間の関係である.

\section{$3 \cdot 5$ 計算結果}

台上試験の確認を前提に図 8 に示すモデルの確認のため, 表 1 に示す車両諸元を設定し, 表 2 に示す制動条件, 温度条件で計算を行う。パッド形状は実験で用いた図 6（a）に示寸扇型で制動有効半径上の摺動長は 88mm, 口

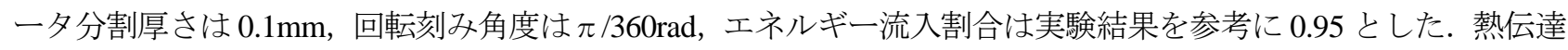
率は, 摩擦面 $80 \mathrm{~J} /\left(\mathrm{s} \cdot \mathrm{m}^{2} \cdot \mathrm{K}\right)$, ベンチレーション面 $85 \mathrm{~J} /\left(\mathrm{s} \cdot \mathrm{m}^{2} \cdot \mathrm{K}\right)$, 密度は $7200 \mathrm{~kg} / \mathrm{m}^{3}$ を用いた. 熱伝導率は $\lambda=65 \mathrm{e}^{-0.00068 T}$ $\mathrm{J} /(\mathrm{s} \cdot \mathrm{m} \cdot \mathrm{K})$, 比熱は $\mathrm{c}=507 \mathrm{e}^{-0.00083 T} \mathrm{~J} /(\mathrm{kg} \cdot \mathrm{K})$ として, 温度 $T\left({ }^{\circ} \mathrm{C}\right)$ の指数関数として用いた. 制動開始から減速が終了 し, 約 $2 \mathrm{~s}$ 後までの速度, 温度の時間軸波形計算結果を図 11 に示寸. 凡例 VT は速度, 数值は摩擦面からの距離 であり単位は[mm]である. 温度が定常状態となる時間 $6 \mathrm{~s}$ では約 $220^{\circ} \mathrm{C}$ 示しており, 実験結果と一致している. また，深さ $0 \mathrm{~mm}$ の温度はパッド通過中に急上昇し，次の入口までに急降下寸る繰り返しが表現されている．制 動開始 1 回転目の計算結果を図 12 に示寸. 横軸はパッド入口からの角度, 縦軸は温度である. 凡例は摩擦面から 
の深さであり $1 \mathrm{~mm}$ までを $0.1 \mathrm{~mm}$ 間隔で表している.深さ $0 \mathrm{~mm}$ すなわち摩擦面温度が最も高い位置がパッド出口 である. 熱電対に近い深さ $4 \mathrm{~mm}$ では, 1 回転の間ではほとんど温度上昇が見られない. 図 12 のパッド通過直後,

90，180，270，360deg の 5 箇所での内部温度を摩擦面からの深さを横軸にとり, 温度を縦軸にとって図 13 に示 す. 摩擦面温度はパッド通過中に約 $77^{\circ} \mathrm{C}$ の昇があり, 入り口までに約 $63^{\circ} \mathrm{C}$ 低下している. 深さ $1 \mathrm{~mm}$ ではパッ ド通過中に約 $1^{\circ} \mathrm{C}$ の昇があり，入り口までに約 $10^{\circ} \mathrm{C}$ 上昇している.

Table 1 Vehicle specifications

\begin{tabular}{|c|c|c|}
\hline Vehicle mass & Tire radius & Brake effectiveness radius \\
$1196 \mathrm{~kg}$ & $0.309 \mathrm{~m}$ & $0.103 \mathrm{~m}$ \\
\hline outer radius & inner radius & Front brake distribution \\
$0.1265 \mathrm{~m}$ & $0.080 \mathrm{~m}$ & 0.7 \\
\hline
\end{tabular}

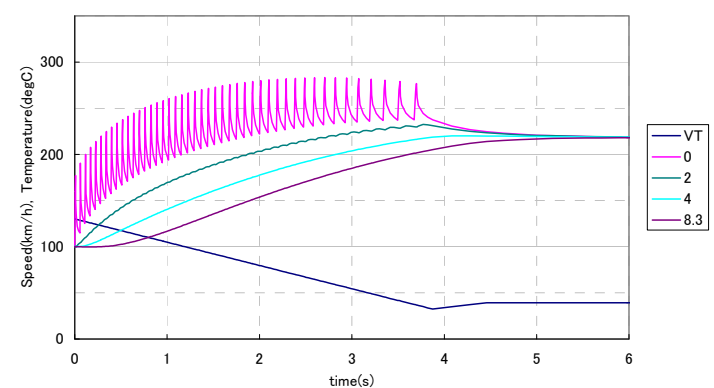

Fig.11 Calcurating result of Pad shape Base.

Time-Temperature and Time- Speed wave form.
Table 2 Braking and Temperature conditions

\begin{tabular}{|c|c|c|}
\hline $\begin{array}{c}\text { Initial speed } \\
130 \mathrm{~km} / \mathrm{h}\end{array}$ & Finish speed & deceleration \\
$35 \mathrm{~km} / \mathrm{h}$ & $7 \mathrm{~m} / \mathrm{s}^{2}$ \\
\hline Initial brake temp. & ambient air temp. & Vent. air temp. \\
$100{ }^{\circ} \mathrm{C}$ & $23{ }^{\circ} \mathrm{C}$ & $23{ }^{\circ} \mathrm{C}$ \\
\hline
\end{tabular}

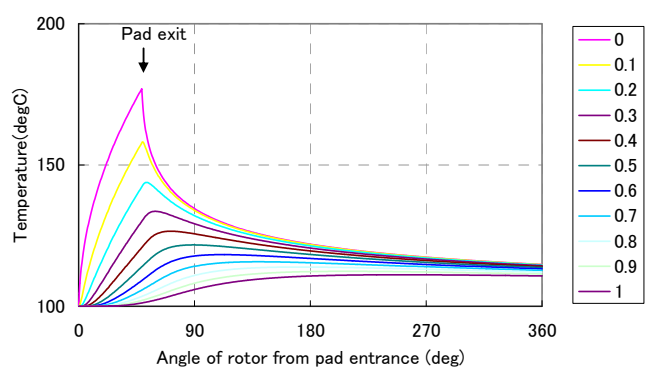

Fig.12 Calcurating result of Pad shape Base.

Angle-Temperature wave form of brake rotor.

この計算では, 厚さ方向分割 $\Delta x=0.1 \mathrm{~mm}$ としている. 摩擦面温度に分割厚さがどの程度影響するかを確認する. 一定減速度の制動を行う場合, パッド通過中の摩擦面温度上昇が最も大きくなる 1 回転目の摩擦面温度上昇で検 討する. 摩擦面温度を考える時 $\Delta x$ は小さいほうが温度上昇は高くなるため, 分割厚さを $\Delta x=0.05,0.1,0.2,0.5 \mathrm{~mm}$ として, パッド出口での深さ方向温度分布を図 14 に示す，凡例は分割厚さを単位[mm]で表している。摩擦面温 度上昇は， $\Delta x=0.5 \mathrm{~mm}$ では約 $62^{\circ} \mathrm{C}$ であり， $\Delta x=0.05 ， 0.1 ， 0.2$ での $75 \sim 77^{\circ} \mathrm{C}$ の温度上昇に比べ $20 \%$ 程度低くな

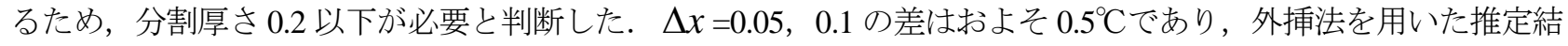

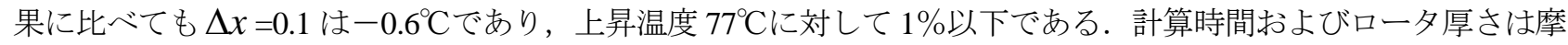
耗でも変化することも考慮して今後の計算は $\Delta x=0.1$ として実用上問題なく, 十分と判断した.

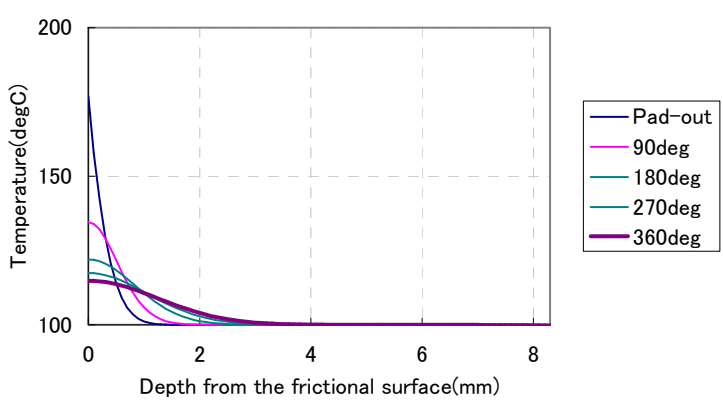

Fig.13 Depth-Temperature wave form of brake rotor, $1^{\text {st }}$ revolution, Graph legends are rotational position.

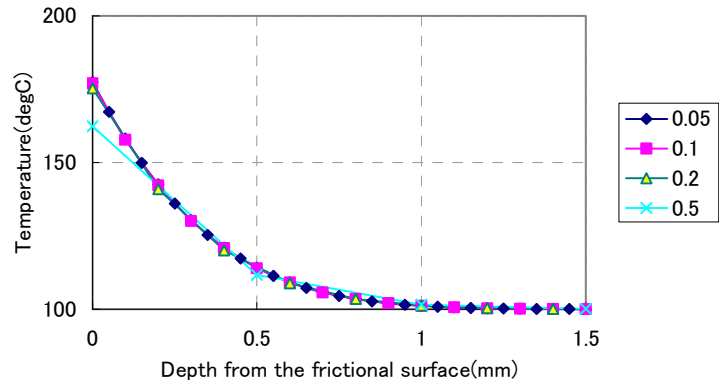

Fig.14 Depth-Temperature wave form of brake rotor. $1^{\text {st }}$ revolution, position is pad exit, every division thickness.

図 11 に示した結果は, 図 12 の 360deg 位置での温度分布を 2 回転目初期条件としている. 以降は逐次初期条件 を入れ替えながら，制動終了車速まで計算を行い，さらに厚さ方向の温度がほぼ一定になるまで空転させる条件 
で計算を行った．最高摩擦面温度は，合計入力エネルギーによる平均温度上昇と車速低下に伴う単位面積入力エ ネルギー率減少によるパッド通過中の上昇温度低下の関係で決まり，この計算例では $2.7 \mathrm{~s}$ 付近に現れる. 制動終 了後は，熱伝導により $1.5 \mathrm{~s}$ 程度で内部と同等な温度になっており，これは熱電対で計測する温度と同等である. 摩擦面から $2 \mathrm{~mm}$ 深い位置では，パッド通過中の温度変化はほとんど見られない．熱電対で計測する範囲に含ま れる $4 \mathrm{~mm}$ 位置では, 制動終了後も温度上昇があり，これは表面からの熱伝導によるものである. ベンチレーシ ヨン側は制動初期，大気一の熱伝達が熱伝導によるエネルギー入力よりも多く，温度上昇が抑制されるが，時間 経過とともに熱伝導によりエネルギー入力が増加して, 温度が上昇する.

\section{4. 実験による計算結果の検証}

\section{$4 \cdot 1$ 摩擦面近傍温度計測}

実際の摩擦面温度を計測することは，2 章でも述べたように非常に困難である．したがって本研究では，摩擦 面温度を計測する代わりに摩擦面から約 $0.2 \mathrm{~mm}$ 深さの温度を特別に改造した熱電対で計測する方法を試みた.ま ず，使用する熱電対は応答性を上げるため,測温部の小さなものを選定し，改造を行った. 熱電対は K 型シース径 $\phi 0.5 \mathrm{~mm}$ を使用した. 熱電対の断面は, 図 15 (a) に示すようにステンレス製のシースの中に先端部分で溶着さ れた $\phi 0.1 \mathrm{~mm}$ 程度の 2 線が，樹脂で保持された構成である. シースおよび樹脂は熱抵抗となるため, 図 15 (b) に示すように研削により除去した．実際の熱電対先端写真を図 16 に示しており， $\quad 0.25 \times 0.17$ の部分が測温部 である。 ディスクロータは, 図 17 に示すように, 計測する反対側の摩擦面から $\phi 3 \mathrm{~mm}$ の穴を計測側のベンチ レーション面まで開け，そこから $0.6 \mathrm{~mm}$ の穴を摩擦面から $0.2 \mathrm{~mm}$ の深さまで開けた. 熱電対はロータにねじで 固定し, 熱電対自体をばねとして， $\phi 0.6$ の穴底に押付けた. 実際に用いたロータを試験後に切断した断面写真を 図 18 に示しており，上部にあるのは金尺で，目盛は $1 \mathrm{~mm}$ 刻夕である. $\phi 0.6$ の穴は深さ約 $0.2 \mathrm{~mm}$ まであいてい ることを確認した.

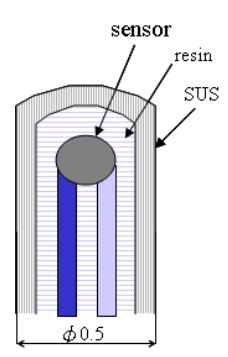

(a) Original

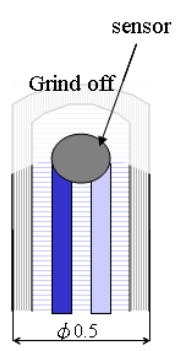

(b) Modification

Fig.15 Section of thermo couple tip.

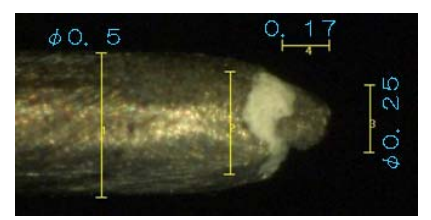

Fig.16 Magnified photograph of thermo couple tip.

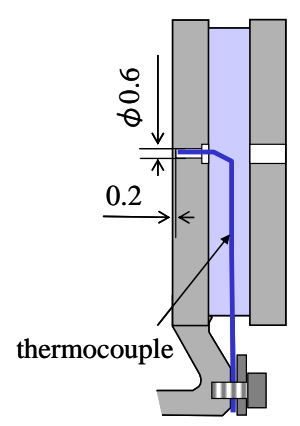

Fig.17 Draft of modification, rotor section.

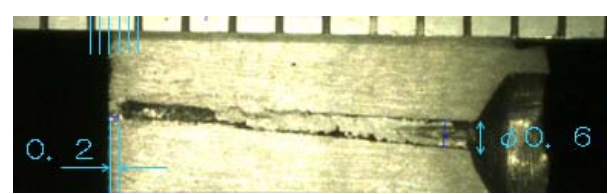

Fig.18 Magnified Photograph of rotor section

\section{$4 \cdot 2$ 摩擦面温度計測結果と計算結果}

製作した供試品を用いて台上試験を行った結果を図 19 に示す. 凡例 $\mathrm{V}$ は速度，0.2 は計測温度である. 試験条

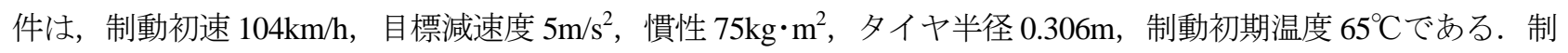
動開始からパッド通過時に温度が急上昇し次のパッド入口までに温度が降下寸る波形が計測された. 実験諸元で の計算結果を図 20 に示しており, 凡例 $\mathrm{V}$ は速度, 数值は摩擦面からの距離を単位[mm]で示しており, その位置 での温度を表している．0.2mm 深さでの温度変化は制動後半の実験結果によく一致している. 


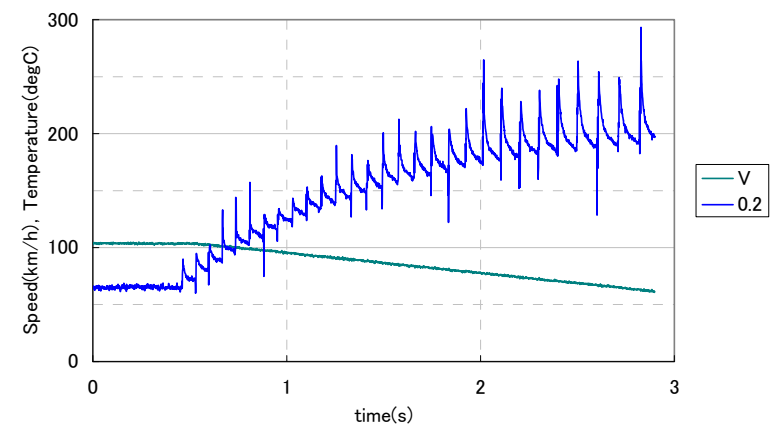

Fig.19 Experimental result, time- temperature depth 0.2mm and speed wave form.

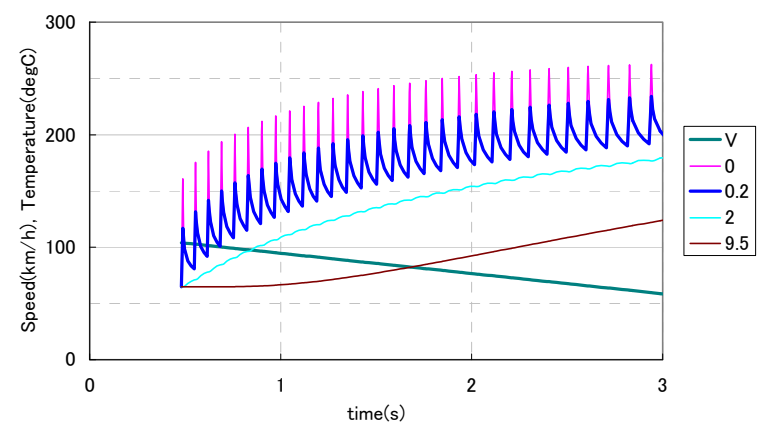

Fig.20 Calculation result, time-rotor temperature and speed wave form.

制動前半のパッド通過時の温度変化が少ないのは，実験では減速度の立ち上がりが遅れること，パッドとロータ の接触状態が変化することが影響していると考えられる. 接触状態の変化に関して, 制動後半ではロータが熱変 形によりアウタ面外周側の面圧が高くなり摩擦力が増加すると考えられる．したがって，計算で用いるブレーキ 諸元は, 平均の温度上昇を考慮して摺動外半径 $0.1515 \mathrm{~m}$, 摺動内半径 $0.1095 \mathrm{~m}$, 片側相当厚さ $0.0095 \mathrm{~m}$, 計算半径 $0.133 \mathrm{~m}$ としている.

\section{5. 摩擦面形状が摩擦面温度に与える影響}

\section{$5 \cdot 1$ 摩擦面形状}

ロータの体積は必要な熱容量でほぼ決まるが，形状は摩擦面温度を考慮して決める必要がある，ここでは，摩 擦面形状が摩擦面温度に与える影響を検討する，ロータ形状は，摺動部の内径，外径を決めれば，体積と製造条 件から厚さが決まる，八ブとの連結部分は，本研究の対象としない，一方，パッド形状は摺動部の内径，外径に 加えて摺動方向の長さが設計諸元となる. 形状の影響を比較するために，制動有効半径，ロータ体積は一定にす る.したがって, 形状諸元はロータ, パッドに共通する内径外径で決まる半径方向巾, パッド摺動方向長さとす る. パッド形状は, 実験で用いた図 6 の（a）Base, （b） R/C, （c） R/Rの3 種類とし，形状（c）R/Rについ ては，体積をあわせたものと実験結果との対比を考慮して厚さを変更したものも検討する.

\section{$5 \cdot 2$ 摩擦面形状違いでの計算結果と考察}

Base 形状の計算結果図 11 と同様に各パッド形状について制動開始から減速が終了し, 約 $2 \mathrm{~s}$ 後までの計算を行 った結果を図 21 に示寸. Base 形状の計算結果図 12 と同様に制動開始 1 回点目の摩擦面から深さ $1 \mathrm{~mm}$ まで 0. $1 \mathrm{~mm}$ 毎の温度計算結果を各パッド形状について図 22 に示寸. 図 21 , 図 22 の (b) は形状 R/C の結果, (c) は 体積を合わせた形状 R/R の結果，（d）は厚さを合わせた形状の結果を示す。

図 11 および図 21 より, 平均的な温度は, ほぼ安定した時間 6s で, 図 21 (b) 形状 R/C, (c) 体積合わせ形状 $\mathrm{R} / \mathrm{R}$ では約 $220^{\circ} \mathrm{C}$ であり, Base 形状と一致している. しかし，(d) 厚さを合わせたパッド形状 R/R では約 $241^{\circ} \mathrm{C}$ と高くなっている．この結果からも平均的な温度は，体積で決まる熱容量の影響が大きいことがわかる.

つぎに (b) 形状 R/C の摩擦面のパッド入口温度および, 摩擦面から 2, 4, 8.3mm の各深さでの温度変化が, Base 形状と同等である。しかし, 摩擦面のパッド出口温度は Base 形状より, 制動初期に約 $21^{\circ} \mathrm{C}$, 最高温度で約 $20^{\circ} \mathrm{C}$ 高くなっており，合計エネルギー流入量は同じだが，流入率が高い影響と考えられる.

一方で体積を合わせた（c）形状 $\mathrm{R} / \mathrm{R}$ は，摩擦面からベンチレーション面まですべての温度変化が異なってい る. 摩擦面温度に注目すると, パッド入口温度は最高温度で約 $17^{\circ} \mathrm{C}$ 高く, パッド出口温度は制動初期に約 $15^{\circ} \mathrm{C}$, 最高温度で約 $31^{\circ} \mathrm{C}$ 高くなっており, パッド半径方向巾が小さくなるとロータ摩擦面積が小さくなり, 摩擦面温度 が高くなることがわかる. 
ロータの厚さを合わせた（c）R/R 形状の結果を図 21 (d) に示す. 図 7 (c) に示した台上試験結果で油圧を上 昇させる必要がある時間 $1.5 \mathrm{~s}$ の摩擦面温度を図 21 (c) 体積を合わせた形状 R/C の結果と比較すると同等の結果 である. 3 形状を比較すると図 7 に示した台上試験結果で (c) R/R 形状のブレーキの効きが低く変化しているの は，パッド入り口摩擦面温度がパッド形状 Base， R/C に比べて高いことが要因であり，熱容量の差がなくても同 様な結果になると考えられる.

パッド材料によって効きが変化する温度は異なると考えられる．しかし，すでに実績のあるパッド材料でブレ 一キを設計する場合、実績のある車両の摩擦面温度と同等になるパッド，ロータ形状設計を行うことで、必要と されるブレーキの効きを得ることができる．また、新たな材料や新たな形状のブレーキ設計においても、一つの 実験における制動性能を評価しておけば、本論文の解析によって摩擦面温度が推定できるため、多くの形状に関 して実験しなくとも、本論文の解析結果を基に設計を行うことができる.

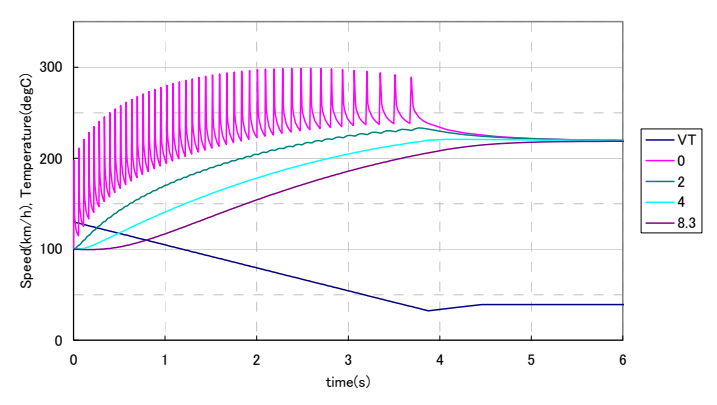

(b)Pad shape R/C.

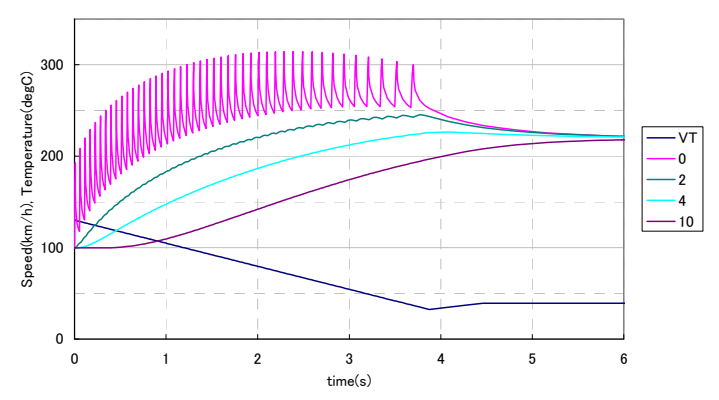

(c)Pad shape R/R, same volume with Base.

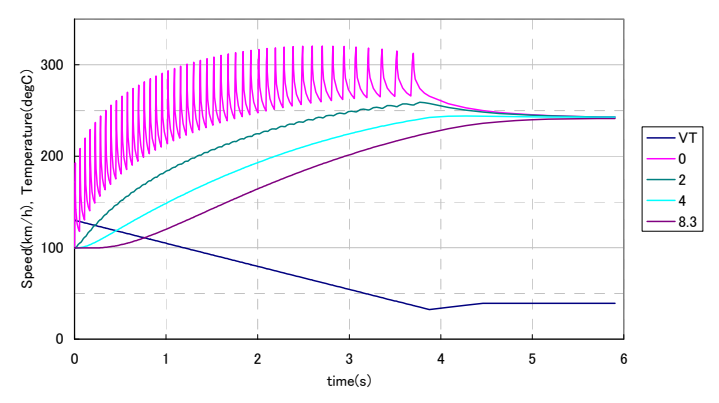

(d) Pad shape R/R, same thickness with Base.

Fig.21 Time-Temperature and Time-Speed wave form, when braking and cooling.

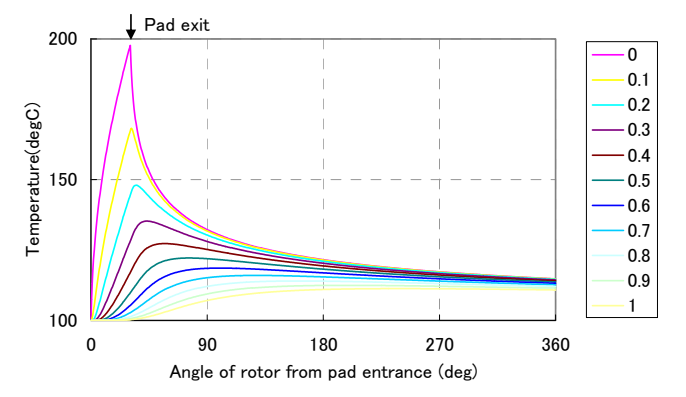

(b) Pad shape R/C.

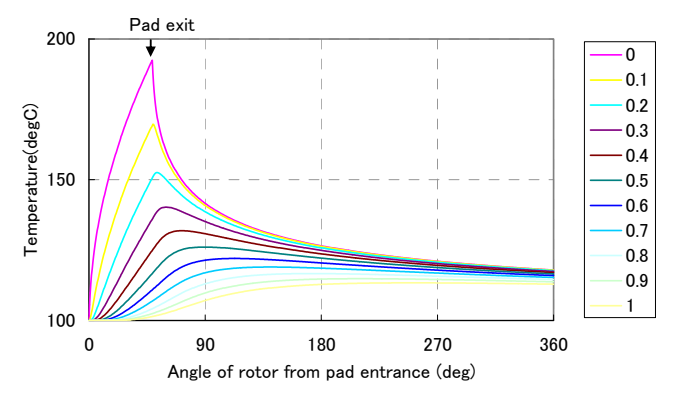

(c) Pad shape R/R, same volume with Base.

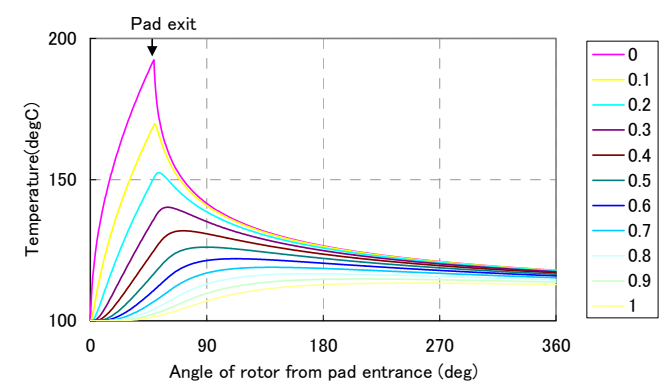

(d) Pad shape R/R, same thickness with Base.

Fig.22 Angle-Temperature wave form of brake rotor, $1^{\text {st }}$ revolution. Graph legends are depth position. 
本研究で得られた以下に記す内容から, 摩擦面温度基準にブレーキの効きが安定する温度領域を把握したうえ で, 摩擦材選定，形状の影響を考慮したディスクブレーキ諸元決定を行うことが，安定した制動性能確保につな がると考える.

1. 主に企画段階での活用を考慮して, パッドとロータの摩擦面温度を推定する計算手法を開発した.

2. 摩擦面から $0.2 \mathrm{~mm}$ 深さの測定温度と本研究の計算結果は, よく一致した.

3. 摩擦面形状毎に数值計算を行い, パッドの半径方向巾がパッド入口摩擦面温度に影響し, パッドの円周方向 巾がパッド入口からの温度上昇に影響することを示した. 台上試験でブレーキの効きが変化したことに対し て半径方向巾の影響が大きいことを示した.

\section{文献}

（1）斎藤彬夫，岡田昌志，一宮浩市，“例題演習伝熱工学”，産業図書株式会社（1985), pp.1-49.

（2）黒田正，”基礎工業数学講座 8 応用編微分方程式”，株式会社朝倉書店（1965)，pp.36-38.

(3) C.H.Gao, J.M.Huang, X.Z.Lin, X.S.Tang, Fuzhou University, "Stress Analysis of Thermal Fatigue Fracture of Brake Disks Based on Thermomechanical Coupling”, Transactions of the ASME (2007） Vol. 129, pp.536-543, JULY

(4) Faramarz Talati, Salman Jalalifar, Faculty of Mechanical Engineering University of Tabriz, Iran, "Analysis of heat conduction in a disk brake system”, Heat Mass Transfer 45 (2009) pp.1047-1059.

(5) 戎圭明, 木須博行, “粒子法によるディスクブレーキの非定常熱解析”, 日本機械学会 2009 年度年次大会講演論文 集(1),(2009), pp.3-4.

(6) 戎圭明, 木須博行, ”SPH 法による傾斜機能材料の非線形熱解析”, 日本機械学会論文集 A 編,Vol.76,No.772, (2010) ,pp.1756-1763. 